Intergenerational justice: a framework for addressing intellectual property rights and climate change

Heather Forrest

Faculty of Law

University of Tasmania

Private Bag 89

HOBART TAS 7001

T-(03) 62262065

$F-(03) 62267623$

E- $\underline{\text { Heather.Forrest@utas.edu.au }}$

Peter Lawrence

Faculty of Law

University of Tasmania

Private Bag 89

HOBART TAS 7001

$T-(03) 62262747$

$F-(03) 62267623$

E-Peter.Lawrence@utas.edu.au 


\section{Intergenerational justice: a framework for addressing intellectual property rights and climate change}

\section{Introduction}

At first blush, one may wonder what contribution normative theory can make to what seems to be such a technical/political issue as the role of intellectual property rights (IPRs) in the global climate change regime. There are two answers to this. Firstly, as eloquently put by Joe Bowersox,

“... normative theory... can be a powerful diagnostic tool for evaluating public policy; it can act as an altimeter, if you will, that checks the thinness of the theoretical air surrounding a particular policy mountain or molehill, telling us whether there is enough oxygen present to support political life. Sometimes theory may even suggest that we try an alternative, less precipitous policy pass by which to cross to the other side." ${ }^{1}$

Conceptions about justice - can provide a valuable framework in terms of ensuring that policy prescriptions are well directed, particularly given that economic policy discourse can bury ethical assumptions. This broader picture, can provide a valuable point of reference in the highly technical debates relating to intellectual property rights and climate change. A second reason for turning to normative theory is the reality that environmental treaties will not be agreed to without at least overlapping conceptions of fairness. ${ }^{2}$ This provides a practical motivation for interrogating more deeply justice discourses involved in the climate change negotiations. To the extent that the current global climate regime is inadequate, shared understandings of justice are a crucial precondition for reforming and making more effective the current climate change regime.

Climate change gives rise to challenging issues of justice - both intragenerational, international and intergenerational. While it is important to remember that serious climate

\footnotetext{
${ }^{1}$ Bowersox (2002), p 247.

${ }^{2}$ See Albin (2001).
} 
impacts are predicted to occur within the lifespan of people alive today, the most serious impacts will be felt by unborn generations, who played no role in creating this situation. Intergenerational justice must be considered in conjunction with intragenerational justice. Large developing countries such as India have an understandable imperative to rapidly develop economically quickly and provide access to energy to the poor. However, if such energy is provided by fossil fuels, it would seem well-nigh impossible to stay within the Paris Agreement's goal of '[h]olding the increase in the global average temperature to well below $2^{\circ} \mathrm{C}$ above pre-industrial levels and to pursue efforts to limit the temperature increase to $1.5^{\circ} \mathrm{C}$ above pre-industrial levels ${ }^{3}$. As argued by Henry Shue, the future poor will be most impacted by unmitigated climate change, and we must find a way of meeting the energy needs of the poor now without sacrificing the interests of the future poor ${ }^{4}$.

The situation of India and other developing countries also raises what could be seen as the first major challenge of applying a theory of intergenerational justice to the problem of intellectual property rights in the climate change context. That is, how to balance intergenerational and intragenerational justice demands. Put differently, who bears responsibility for technology development and transfer and IPRs reform where necessary to meet the challenge of climate change? Does responsibility fall entirely on the shoulders of developed countries or is this a shared responsibility?

Intergenerational justice is important here because it provides a powerful rationale for the rapid roll-out now and further development of low carbon technologies which is arguably the key to any successful strategy likely to meet both inter and intra-generational justice demands. While the rationale for IPRs has been the incentive they provide to innovation, IPRs - particularly patents - have also come to be seen as constituting barriers to the development and diffusion of climate change-related technologies. To the extent that the global system of IPR acts as a barrier to such technology development and transfer, it should be reformed to ensure that it facilitates rather than hinders this process.

\footnotetext{
${ }^{3}$ Paris Agreement to the United Nations Framework Convention on Climate Change (adopted 22 April 2016, entered into force 4 November 2016) http://unfccc.int/files/essential background/convention/application/pdf/english paris agreement.pdf (Paris Agreement). ${ }^{4}$ Shue (2014), p 315.
} 
A second key challenge in applying intergenerational justice in relation to this field, is the question of whether the current generation bears a particular responsibility to take strong action in response of climate change - distinct from - and greater than - the responsibility of previous generations, given its position of having the last chance to take strong mitigation action to avoid a significant risk of catastrophic climate change $e^{5}$. This is in a context where scientists maintain that global GHG emissions must start to go down within the next few years at the latest and then decline further toward zero emissions by $2050 .{ }^{6}$ This creates dissonance with intergenerational justice theories which have relied on a notion of each generation being under an equal burden in terms of obligations towards the future. In this chapter we argue that this notion of "last chance responsibility" has a number of important implications in terms of policy positions related to the debate surrounding intellectual property rights and climate change.

These two key challenges are addressed in this chapter, which is structured as follows. Section 2 sets out a theory of intergenerational justice. Section 2.1 examines the question of whether this theory places a particular responsibility on industrialised countries for reforming the global IPR system in light of the climate change challenge. Section 3 turns to examine the global IPR system in light of this intergenerational justice framework, setting out (in 3.1) a short overview of the global intellectual property rights framework and how it functions. An analysis is made in terms of how the current system is biased in favour of the interests of the North vis-à-vis the South, and also biased in favour of current vis-à-vis future generations. Section 3.2 discusses how intellectual property rights relate to climate change mitigation efforts. Section 3.3 outlines how the intellectual property rights issue has been dealt with in the global climate regime. This chapter does not pretend to provide an authoritative answer in relation to the controversy as to whether intellectual property rights serves as a barrier or facilitator to action on climate change, but aims to show how an intergenerational justice framework can provide a fresh and sharper perspective in analysing this debate which makes explicit key normative assumptions. Section 4 draws conclusions.

\footnotetext{
${ }^{5}$ Shue (Nov 2015).

${ }^{6}$ UNEP (2016) Emissions Gap Report, p 9.
} 


\section{Intergenerational justice}

There is no single theory of intergenerational justice. Applying justice principles in relation to unborn generations throws up particular challenges. Thus theories based on reciprocity face what seemed to be an insurmountable hurdle, given future generations' inability to reciprocate in relation to current generations. ${ }^{7}$ Furthermore, Rawlsian and other theories premised on continual progress and/or each generation having the same obligations seem ill suited to the current context where we are facing an environmental catastrophe.

(Lawrence 2014) has argued for a theory built on the work of Simon Caney and Henry Shue, which, in summary, involves the following elements:

These are as follows:

P1 Equality principle: All persons born now and in the future are entitled to certain core human rights (to life, health and subsistence) ${ }^{8}$.

P2 Harm avoidance principle: Contemporaries have an ethical obligation to avoid harm, including to the interests and core human rights of future generations including their right to a healthy environment. ${ }^{9}$ The flip side of the harm avoidance principle is:

P3 Responsibility for harm principle: a person who caused harm to the interests of othersand no one else-is responsible for clearing up this harm and/or compensation proportionate to their share of the damage.

P4 Capacity to pay: Among a number of parties, all of whom are bound to contribute to some common endeavour ${ }^{10}$.

\footnotetext{
${ }^{7}$ Lawrence (2014), pp 48-50.

${ }^{8}$ Lawrence (2014), p76 which builds on Simon Caney's work. Note some authors extend these core rights to also include the right to a healthy environment, see e.g. Hayward (2005), and Vanderheiden (2008), who argues for a right to a stable climate system, p 241.

${ }^{9}$ For a similar harm avoidance principle see Vanderheiden (2008), p 137, and Lawrence (2014), pp 29-66.

${ }^{10}$ Lawrence (2014), p 86 relying on Shue (1999), p 531.
} 
P5 Effectiveness principle: In order to meet the requirements of P1,P2, P3 and P4 ie to avoid harm to the core human rights of future generations, governments should negotiate an effective global climate regime. As mentioned above, "Effectiveness" has been agreed by the international community in the $1.5^{\circ} \mathrm{C} / 2^{\circ} \mathrm{C}$ Paris Agreement objective.

These ethical principles rest on widely shared values. The notion of all persons being equally entitled to core human rights is found in the near universal support for the Universal Declaration on Human Rights (UDHR) and the major human rights treaties. ${ }^{11}$ These treaties and the UDHR enjoy near consensus support from the international community. Since 2006 even China accepts the universality of human rights while placing emphasis on 'survival rights of subsistence' - socio-economic rights - over civil and political rights. ${ }^{12}$

While the right to property is included as a human right in major human rights treaties, here we follow the logic of Henry Shue who argues that property is not a core human rights but rather a vehicle for securing the more basic human rights to subsistence and life. ${ }^{13}$ The fact that one could enjoy a right to life and subsistence in a social system which did not contain private property rights underscores this point.

Climate change threatens a number of well-established human rights, such as the rights to life, health and subsistence. ${ }^{14}$ Unmitigated climate change threatens the rights of persons alive today. Thus, if one imagines a person born today, that person in 2050 will be 32 years old. A 50 year old politician will in 2050 be 82 years old. Thus climate change will seriously impact current generations within their lifetime, with increased mortality from extreme weather events and tropical diseases. ${ }^{15}$ But the most severe impacts will be felt by unborn

\footnotetext{
${ }^{11}$ Donnelly (2007), p 281.

Note that we do not wish to imply that a broader range of human rights can also be the basis of a more comprehensive theory of intergenerational justice. It is however, sufficient to base a strong ethical obligation towards future generations on the more limited list of human rights contained in the theory described here. 12 Sceats and Breslin (2012), p 8.

${ }^{13}$ Shue (1980), p 24 \& p 125.

14 Caney (2009b), p 167. Some argue that future unborn persons cannot possess human rights at all. Even if this were to be true, as a minimum, persons upon being born possess human rights, and we therefore have a corresponding ethical obligation to ensure that such rights are not infringed, Vanderheiden (2008), p 129. 15 IPCC. (2014). Intergovernmental Panel on Climate Change (IPCC) (2014), Fifth Assessment Report, Climate Change 2014: Working Group II: Impacts, Adaption and Vulnerability, Summary for Policymakers (2014) <http://ipcc-wg2.gov/AR5/images/uploads/IPCC_WG2AR5_SPM_Approved.pdf> accessed 7 May 2014.
} 
generations and these future generations will face risks of irreversible harm to the global ecological system and climate. The recently released IPPCC $5^{\text {th }}$ Assessment Report highlights some of these risks including the likelihood of meltdown of the Greenland ice sheet. ${ }^{16}$

It is important to recognise that human rights alone cannot provide a coherent theory of intergenerational justice. The potential conflict between the interests and rights of persons alive today and in the future can only be resolved by application of a distributive justice principle, whether this be a principle of equality, subsistence or priority to the poor, for example. ${ }^{17}$ Distributive justice principles with the greatest chance of being implemented should rest on values already widely supported in the global system. Thus for example, the notion of equality, which is already embedded in the Universal Declaration on Human Rights in terms of each person being equally entitled to human rights can be extended into the future within a theory of intergenerational justice. Similarly the notion of justice and subsistence, involving the idea that the poor should not be allowed to fall below a certain threshold required for human dignity, is well reflected in the 2015 UN millennium goals. ${ }^{18}$

\subsection{Who is responsible for technology development and IPRs reform?}

If one accepts the theory of intergenerational justice sketched above, what does this tell us in terms of who bears ethical responsibility for the development and I diffusion of technology necessary to address mitigation and climate adaptation, and linked to this who bears responsibility for ensuring that the IPR system is reformed so as to not provide a barrier with regard to technology development and transfer?

The principles outlined above are expressed in a manner relating to ethical responsibility of individuals. Translated to the global level in terms of responsibility of governments, the responsibility for harm principle and the notion of proportionate responsibility for harm, together with the capacity to pay principle both point towards industrialised countries being primarily responsible for making available the technologies necessary for climate change

\footnotetext{
${ }^{16}$ IPCC, $5^{\text {th }}$ Assessment Report, The Physical Basis, Summary for Policymakers, http://www.climatechange2013.org/images/uploads/WGIAR5-SPM_Approved27Sep2013.pdf accessed 7 October 2013.

${ }^{17}$ Caney (2009a), p 163.

18 UN Millennium Development Goals www.org/milleniumgoals/poverty.shtml.
} 
mitigation. This acknowledges the role of industrialised countries in being primarily responsible for causing the problem and in relation to the benefits which developed countries have enjoyed in industrialisation and in relation to which it would be unfair to deprive developing countries.

Making industrialised countries entirely responsible in this regard would be problematic for a number of reasons. Firstly, the share of global cumulative greenhouse gas emissions has shifted towards developing countries. ${ }^{19}$ Secondly, the nature of technology development and transfer is not linear in the sense that technology and associated IPRs can simply be transferred to developing countries. Forsyth and others have pointed out that the successful transfer of low carbon technology in Clean Development Mechanism (CDM) projects in Asia for example, has been linked very much to domestic factors, including how much projects mesh with local priorities and values ${ }^{20}$. Thus, it makes more sense to consider technology development and transfer as a shared and proportionate - with the amount of responsibility proportionate to capacity to pay and historic emissions. This in no way implies that industrialised countries should be let off the hook in terms of the necessity to fund the Green Climate Fund and other international funding mechanisms which must play an essential role for the rapid development and diffusion of low carbon technology. The notion of proportionate responsibility, acknowledges that take up of low carbon technology depends on regulation in both industrialised and developing countries, in terms of placing a price on carbon, which is essential in terms of avoiding the "valley of technological death" which can occur if there is no "market pull" to ensure commercialisation of low carbon technologies ${ }^{21}$.

The notion of shared and proportionate responsibility is crucial as a mechanism for balancing the potentially conflicting interests of future and current generations.

\footnotetext{
19 Technical Summary. In: Climate Change 2014: Mitigation of Climate Change. Contribution of Working Group III to the Fifth Assessment Report of the Intergovernmental Panel on Climate Change - Total Anthropogenic CO2 Emissions from Fossil Fuel Combustion, Flaring, Cement, as well as Forestry and Other Land Use (FOLU) by Region between 1750 and 2010 ( $p$ 43) reveals that developing countries' cumulative emissions had (in 2010) already overtaken developed countries' cumulative emissions. https://www.ipcc.ch/pdf/assessmentreport/ar5/wg3/ipcc_wg3_ar5_technical-summary.pdf. ${ }^{20}$ Forsyth (2005), pp 165-176.

${ }^{21}$ Philibert C (2004) International Energy Technology Collaboration and Climate Change Mitigation, OECD paper com/ENV/EPOC/IEA/SLT
} 
Importantly, this conflict can be substantially avoided if we take intergenerational justice seriously and governments are pushed to rapidly develop and transfer the required technologies.

\subsection{A special responsibility on the shoulders of current generations?}

Given the potential for catastrophic harm occurring to future generations (and even to young persons alive now, within their lifespan), intergenerational justice requires strong and decisive action to mitigate climate change. The most important consequence of the theory of intergenerational justice sketched above is in terms of urgency. Some theories of intergenerational justice emphasise that each generation should have an equal burden. This does not make sense in relation to the current crisis - carefully distributing the mitigation burden in an equal manner over a number of generations would fail the test of avoiding avoidable harm implicit in the harm avoidance principle described above.

If one accepts that the current generation - particularly the wealthy who enjoy luxury emissions - have a particular responsibility - distinct from other generations - to do all it can to mitigate greenhouse gas emissions, what implications would this have for the debate on climate change and IPRs? We would argue that ethical responsibility requires that IPRs should bend to meet this emergency. Thus, to the extent that IPRs do indeed constitute a barrier to technology development and transfer, intergenerational justice considerations would point to the need to modify - and provide a framework for modifying - the rules to take into account the current crisis.

It is outside the scope of this chapter to set out precise details in terms of IP reform or compulsory licensing or other options. What is important is ensuring an effective response so as to avoid harm to future generations, while also addressing intragenerational justice imperatives. So the emphasis needs to be encouraging and rewarding technology development and diffusion as a vehicle to meeting the requirement of rapid mitigation of greenhouse gas emissions. It may be that - at least to some extent - this objective can be met by mechanisms within the existing global IPRs system, such as compulsory licensing in relation to patents, patent pooling and funding of IPRs transfer. However, to the extent that 
more thoroughgoing reform is required, as argued by eg Rimmer, ${ }^{22}$ the effectiveness principle integral to intergenerational justice requires the IP regime to be reformed to ensure an effective response in terms of reduction of emissions. To provide the context for this to occur, we now turn to an analysis of the intellectual property regime and how it relates to climate change-related technologies.

\subsection{Intellectual property rights - problem or solution to climate change mitigation?}

Contemporary intellectual property law draws from a longstanding reliance on the moral imperative or necessity of rewarding those who create. ${ }^{23}$ Intellectual property rights, the argument goes, encourage innovation and investment, and thereby improve society. Conversely, without intellectual property rights, creators and innovators are not sufficiently incentivised to create, and society suffers.

Environment advocates have good reason to question these foundational notions. Do intellectual property rights encourage innovation and investment in technologies vital for climate change mitigation? Without intellectual property rights, would climate change mitigation efforts suffer? Or would such efforts perhaps be better served without intellectual property rights? ${ }^{24}$ Environment advocates appropriately join those in other sectors asking these questions, ${ }^{25}$ for if intellectual property rights are intended to be a key driver of new and innovative solutions to society's problems, and data suggests increased use being made of the intellectual property system, where are the promised advances in climate change mitigation?

The economic growth thesis that is supported and enabled by intellectual property rights argues 'that institutions set a country upon the path to rags or riches. Property rights, especially private property rights, are generally the heroes of the story. ${ }^{26}$ This thesis 'raises

\footnotetext{
22 Rimmer (2011).

${ }^{23}$ Beckerman-Rodau (1994), p 603.

${ }^{24}$ Dutfield and Suthersanen (2008), p 6 ('even if one accepts the economic and strategic importance of knowledge, it is not necessarily to be concluded that the more intellectual property you have and the stronger the rights are better, or even that intellectual property is necessary at all. One may more safely conclude that intellectual property policy-making is a high stakes exercise and is consequently an inherently political activity.').

${ }^{25}$ See, eg, Rimmer (2011); Blakeney (2013), p 433.

${ }^{26}$ Drahos (2011), p 31.
} 
the possibility that IPRs might have a key role to play in helping the world to avoid catastrophic climate change. But there is another possibility. Extractive IPRs might impede us from innovating to save ourselves from the coming storms. ${ }^{27}$

Various explanations have been offered for this conundrum. Some say the intellectual property system (within which patent law in particular) will not facilitate climate change mitigation: 'the patent institution will do little to drive the big science that is needed, especially in the energy sector, to avoid the worst climate change scenarios. ${ }^{28}$ Others say that the intellectual property system (and again, patent law in particular) is not capable of facilitating climate change mitigation: as is described in more detail below, the international intellectual property framework merely reinforces the North-South divide, hindering rather than encouraging technology development and transfer to marginalised economies. ${ }^{29} \mathrm{At}$ their heart, both complaints charge patent law - and by implication, all intellectual property law - with failure to deliver on its key promise. We question more specifically whether intellectual property rights might be impeding innovation today in the field of climate change mitigation, favouring instead technologies more lucrative in the immediate term while assuming that future generations will be sufficiently incentivised to innovate in less certain, less lucrative climate change technology when the urgency is more apparent.

To address these concerns, one must first appreciate the nature of intellectual property rights and their intended function and purpose. A clear understanding of the scope of protected subject matter and the rationales for affording them legal recognition through private property rights is required if the concerns of climate change policy-makers are to be reasonably responded to. It is all too easy and predictable to blame intellectual property rights, as has regularly been done in the past. ${ }^{30}$ Expressing the view that the intellectual property system is broken ${ }^{31}$ takes us only so far; proposing a solution without clearly

\footnotetext{
27 Drahos (2011), p 33.

28 Drahos (2011), p 45.

${ }^{29}$ Richardson and Gaisford (2017).

${ }^{30} \mathrm{See}$, eg, Intellectual Property: The cost of ideas, The Economist, 11 Nov 2004; Inside Views: The Downfall of Invention - A Broken Patent System, Intellectual Property Watch, 18 Aug 2016; Mossoff, Adam and Sichelman, Ted M., Letter to Congress from 28 Law Professors \& Economists Urging Caution on the VENUE Act (August 1, 2016). Available at SSRN: https://ssrn.com/abstract $=2816062$

${ }^{31}$ See, eg, Jaffee and Lerner (2006); Bessen and Meurer (2008). Greenhalgh and Rogers (2010).
} 
identifying the problem risks wasting resources on a solution needing a problem at best, or a completely unsuitable 'solution' at worst. In short, before proposing to resolve the problem, we must frame the problem.

Framing the so-called problem of the so-called failure of intellectual property rights involves looking at these issues from a new (and unashamedly provocative) perspective. Framed in this way, we question whether the core problem is not that the intellectual property system is failing to deliver on its key promise, but rather posit that it may be over-delivering on that promise. To the extent that the intellectual property system incentivises innovation in the most immediately lucrative and easily commercialised fields (such as 'lifestyle drugs' ${ }^{32}$ for such wealth-related conditions as diabetes, obesity and impotence) and not in longer-term solutions to problems not yet fully appreciated or conceptualised or valued such as climate change mitigation technology, then perhaps it is not new (or no) intellectual property laws that we need, but a lense for evaluating and reforming. In analysing this issue, intergenerational justice leads us to focus on the time element in relation to the existing intellectual property law framework; to the extent that the urgency aspect of climate change mitigation is not taken into account, this must change. The imperative of rapid dissemination and uptake of low carbon technologies means that the time element in existing institutions and rules becomes crucial.

\subsection{Role and Rationale of intellectual property rights applied to climate change mitigation}

\subsubsection{The intellectual property rights framework and how it functions}

i) Intellectual property: more than just patents

Understanding the linkages between climate change mitigation and intellectual property rights requires as a starting point an understanding of what falls within (and without) the scope of intellectual property rights. A plain meaning interpretation equates intellectual property with products of the mind that are legally recognised through the conferral of private property rights which give the rights holder certain 'freedom... over their creations.' ${ }^{33}$ Put another way, '[i]ntellectual property is often the propertization of what we

\footnotetext{
32 Collier (2013) p 185. ${ }_{33}$ Karky (2016), p 213.
} 
call "talent."'34 Such simplified definitions highlight key characteristics of intellectual property, but they lead all too easily to the unwarranted assumption that all intangibles that derive value from their contribution to human culture, information or entertainment fall within its basket.

Formal definitions make clear that intellectual property is not a refuge for all creative or potentially profit-generating expression or innovation, ${ }^{35}$ but do so by requiring that protected subject matter fit within identified categories. ${ }^{36}$ Article 2(viii) of the Convention Establishing the World Intellectual Property Organization (the 'WIPO Convention'), ${ }^{37}$ for example, defines the term as including 'the rights relating to:

- literary, artistic and scientific works,

- performances of performing artists, phonograms, and broadcasts,

- inventions in all fields of human endeavor,

- scientific discoveries,

- industrial designs,

- trademarks, service marks, and commercial names and designations,

- protection against unfair competition,

and all other rights resulting from intellectual activity in the industrial, scientific, literary or artistic fields.'

While the WIPO Convention's use of inclusive language clearly leaves room for future expansion, the TRIPS Agreement appears to be more prescriptive, defining 'intellectual property' as 'all categories of intellectual property that are the subject of sections 1 through 7 of Part II' of that agreement. Prescriptiveness has not borne out in practice, however, with subject matters not expressly articulated in Article 1(2) having been deemed to fall within its scope. ${ }^{38}$ Further, it is increasingly difficult in the current social and economic climate to

\footnotetext{
${ }^{34}$ Hughes (1988) p 287 and 291.

${ }^{35}$ Forrest (2017), p 170.

${ }^{36}$ See, eg., Drahos (2011), pp 30-31 ('"Intellectual Property"... is a generic term used to refer to independent statutory or non-statutory systems such as patents, copyright, trade marks and trade secrets.')

${ }^{37}$ Convention Establishing the World Intellectual Property Organization (14 Jul. 1967, entered into force 26 Apr. 1970), 828 U.N.T.S. 3.

38 United States - Section 211 Omnibus Appropriations Act of 1998, 41 I.L.M. 654 (W.T.O. D.S.B. App. Body 2 Jan. 2002). (interpreting 'intellectual property' to include not only the categories indicated in each title of each section of Part II of the TRIPS Agreement, but also categories of intellectual property subject to each section of Part II)
} 
argue that new subject matter falling within the general conception of intellectual property is not 'trade-related' ${ }^{39}$

These definitions make clear that patents are notably but one of multiple categories of intellectual property right, and yet they tend to be explicitly targeted in framing the failings of the intellectual property system vis-à-vis climate change mitigation. Certainly innovations such as a method for 'operating a wind turbine generator during an abnormal power grid event', ${ }^{40}$ a 'concentrated solar power light tube illuminating apparatus'41 and a 'gravitypowered electricity generator', ${ }^{42}$ each the subject of current patent protection, are relevant to the overall efforts to mitigate climate change. A by-product of intellectual property rights' absorption into the trade agenda and thus commercialisation, however, is the spawning of suites of rights around each creation. Working symbiotically, contemporary intellectual property laws and the economy have made it 'economically more feasible... to invest in organized large-scale in-house research and development ${ }^{\prime 43}$ and build a portfolio of rights around each output of that research and development. Alongside each patent sits a host of corresponding trade marks, designs and copyright works in the form of manuals, guides, reports, drawings, sketches, videos, databases, photographs, and brand names.

The broad coverage of intellectual property must be borne in mind when considering the role of IPRs in the mitigation of climate change. 'Intellectual property' is not, in the context of climate change mitigation or indeed any other context, a homogenous thing, and the protection of the different categories of subject matter may be motivated by differing objectives. Differing scope and duration of protection across the various rights, and the increased incidence of protecting a single idea through a complex portfolio of intellectual property rights, complicates matters further. This is discussed in further detail below. Nor is intellectual property 'a static conception'; rather, it 'is in a state of constant evolution and reconsideration. ${ }^{44}$ In this evolutionary process, there is a clear trend in the expansion,

\footnotetext{
${ }^{39}$ Gervais (2012).

${ }^{40} \mathrm{WO} / 2017 / 202428$

${ }^{41}$ PCT/CN2017/085600

42 WO/2017/197847

43 Dutfield and Suthersanen (2008), p 109.

44 Dutfield and Suthersanen (2008), p 14.
} 
rather than contraction, of the subject matter categories deemed to fall within the concept of intellectual property. While this expansion has been broadly consistent with the various attributes of intangibility, origin in the human mind and non-perishability attributed over time to intellectual property subject matter ${ }^{45}$ the likely impetus for expansion is not that conceptual consistency, but rather the potential for commercialisation - recouping the investment of resources in innovating. Herein lies the promised incentivised reward of the grant of a limited monopoly in the form of private property rights. This is of course manifestly reflected in the name of the most recent and all-encompassing international treaty on intellectual property rights, a fact that may be lost when its full name 'TradeRelated Aspects of Intellectual Property Rights Agreement' is reduced to the simpler and more often used acronym 'TRIPS'.

The reliance on categories of subject matter, the fluidity of those categories, and the pace of contemporary human development make it impossible to draw up a conclusive list of all of the many touchpoints between intellectual property rights and climate change mitigation. The relevance of intellectual property rights to climate change mitigation is nevertheless clear, and dynamism of the concept assures that relationship into the future.

ii) The globalised intellectual property framework and its effects

The ability of law and policy makers to adjust domestic intellectual property law to support national climate change negotiations is curtailed by the globalised approach taken since the late nineteenth century. True to the meaning of 'globalisation', the international intellectual property law framework 'create[s] and consolidate[s] a unified world economy, a single ecological system and a complex and dynamic network of communications that covers the world. ${ }^{46}$ They do this by establishing a baseline of minimum standards; all must meet the baseline protections, any may opt to exceed the baseline. Further, the minimum standards are, on the whole, articulated in general terms so that signatories may employ language that addresses national norms and priorities. Thus, 'sovereign states still try to work as

\footnotetext{
${ }^{45}$ See Beckerman-Rodau (2011).

${ }^{46}$ Dutfield and Suthersanen (2008), p 3 . Note "ecological system" here refers to the global context and not the environment.
} 
independent actors, where there is room for them to negotiate or legislate variations, and attempt to protect their own interests. ${ }^{\prime 47}$

In principle, this in-built flexibility provides some freedom to take national priorities into account within the agreed framework of 'what intellectual property is all about', ${ }^{48}$ but in reality 'developing countries implementing new multilateral or bilateral intellectual property agreements find their interpretative scope concerning rights, exceptions and limitations curtailed or limited' by the interpretations of major trading partners the European Union and the United States, which 'sometimes intervene and discourage' countries from interpreting treaties in line with local conditions. ${ }^{49}$ The benefits of harmonised registrability standards and protection scope so earnestly sought 150 years ago have thus been tainted by accusations of 'the imposition of colonialist/imperialist ideals for the propertisation of the expression of human intellect on developing nations. ${ }^{50}$ Thus the TRIPS agreement is an essential part of a global trade and economic system which involves structural intragenerational injustice in terms of the interests of developing vis-à-vis developed countries. ${ }^{51}$

While the international intellectual property conventions make it fairly uncontroversial to offer more than the minimum standards baseline, the inverse is not true. Exemptions are envisaged but are subject to challenge. ${ }^{52}$ With the strategic absorption of intellectual property rights into the trade agenda in 1994, meeting the minimum standard framework became a condition of full participation in the global market. Developing countries, of course tend to be seldom in the position of enforcer, and almost always in the position of violator, understandably bitter as to why they are being held to standards of intellectual property which industrialised countries only adopted late in their industrialisation process. The TRIPS Agreement is not, however, completely ignorant of the tensions inherent in

\footnotetext{
47 Perry M (2016), p 7.

48 Hughes, p 293.

${ }^{49}$ Dutfield and Suthersanen, p 4. See also Drahos, p 39 in Emerging Challenges in Intellectual Property. (posting that the 'global command structure for patents means states have less freedom to use patent rules adaptively.').

50 Perry, The Changing Face of Intellectual Property, p 1.

51 Ciplet D, Timmons Roberts J and Khan MR (2015) Power in a Warming World: The New Global Politics of Climate Change and the Remaking of Environmental Inequality, MIT Press.

52 de Vuyst B et al (2003) Exceptions to Intellectual Property Rights: Lessons from WTO-TRIPS Panels' 10(4), Murdoch University Electronic Journal of Law.
} 
imposing a single, unifying approach to intellectual property rights across a wide variety of economies, cultures and legal systems. Nor is the TRIPS Agreement ignorant of the inherent balancing that takes place in intellectual property rights between creators and users. Indeed, it is even argued that 'TRIPS has reinforced the public nature of intellectual property rights in a way that WIPO had never done before, and indeed had been at pains to avoid doing. ${ }^{53}$ Specifically, Article 7 of the TRIPS Agreement provides:

The protection and enforcement of intellectual property rights should contribute to the promotion of technological innovation and to the transfer and dissemination of technology, to the mutual advantage of producers and users of technological knowledge and in a manner conducive to social and economic welfare, and to a balance of rights and obligations.

Article 8 separately provides:

1. Members may, in formulating or amending their laws and regulations, adopt measures necessary to protect public health and nutrition, and to promote the public interest in sectors of vital importance to their socio-economic and technological development, provided that such measures are consistent with the provisions of this Agreement.

2. Appropriate measures, provided that they are consistent with the provisions of this Agreement, may be needed to prevent the abuse of intellectual property rights by right holders or the resort to practices which unreasonably restrain trade or adversely affect the international transfer of technology.

These articles notably have no equivalents in the WIPO conventions, lending support to the observation that the TRIPS Agreement has at last expressly acknowledged what was previously the elephant in the room obvious to all but called out by none, the 'linkages between human rights and intellectual property rights, including public health, nutrition, environment, innovation and development. ${ }^{\prime 54}$ Yet two moderating factors distinguish them from the broader TRIPS agenda, however. First, they are framed in discretionary, rather

\footnotetext{
53 Dutfield and Suthersanen (2008), p 14.

54 Dutfield and Suthersanen (2008), p 223.
} 
than mandatory, language. Second, article 8 makes clear that taking social considerations into account cannot come at the expense of compliance. ${ }^{55}$

On the other hand, a TRIPS Agreement without articles 7 and 8 would arguably be an entirely different animal. From these two articles several key principles can be extracted. First, there is express acknowledgement and effective codification of the notion that intellectual property rights recognition is an effort in balancing the (often conflicting) interests of creators and users. Second, there is express acknowledgement, where this was not achievable over the more than 100 years prior, of both the social and economic welfare impacts of intellectual property rights. Third, there is acknowledgement and furthering of the belief that a key function of intellectual property rights is incentivisation. None of these basic tenets is inherently incompatible with climate change mitigation.

While the existence of a globalised intellectual property system brings challenges and constraints, it is unquestionably the case that a balkanised approach of differing intellectual property norms (as to what is protectable, duration of protection, scope of protection, etc) across jurisdictions would bring its own challenges and constraints. The so-called problem with intellectual property rights is not, therefore, simply that the intellectual property laws of developed nations have been wrapped into trade agendas and imposed on developing nations with weaker relative negotiating authority. The problem, such as it is, is the philosophies and objectives underpinning the intellectual property laws of the developed nations that drive the international framework.

\subsubsection{Why we protect intellectual property, and how this relates to climate change mitigation}

Questioning the need for and rationale of intellectual property protection is certainly not a new phenomenon. Intellectual property laws have survived (and arguably even thrived in spite of) innumerable attacks. In recent times, these attacks have been fended off largely by the sacred status accorded to economic growth. By linking intellectual property rights recognition and enforcement to economic growth, intellectual property rights inherit some

\footnotetext{
55 Dutfield and Suthersanen, (2008) p 34 ('the proviso that such measures be consistent with the provisions of TRIPS appears to narrow their possible scope quite considerably.')
} 
of that sacred status. Enticing assertions such as 'intellectual property fuels economic development and drives growth... and [i]ncreased intellectual property protection boost[s] multilateral/bilateral trade and investment ${ }^{56}$ are difficult for governments, with their weighty fiscal responsibilities, to ignore. Couched in patriotic terms, they are even harder to resist. $^{57}$

But in recent decades, the mantra of economic growth has been strongly challenged in terms of whether it is consistent with addressing global ecological threats such as climate change. In response to these challenges, the WTO Marrakesh agreement has inserted into the preamble reference to "sustainable development" in its listing of the objectives of the WTO. Moreover, this preamble language has been referred to in jurisprudence of the WTO in interpreting provisions of WTO agreements relevant to conflicts between environment and trade objectives. ${ }^{58}$ Nevertheless, in general terms, this amendment to the WTO agreement has done little to modify the overarching ethos of the organisation's focus on ever expanding trade and economic development. The WTO and its members have done nothing to curb massive fossil fuel subsidies, and have failed to reform its current rules on subsidies which has resulted in more than half a dozen successful challenges against countries introducing renewable energy schemes ${ }^{59}$.

Sweeping statements linking intellectual property with economic growth suggest a particular rationale for and intended role of intellectual property. Precise identification of this rationale/role is not simply philosophising or retrospective navel-gazing, but rather is necessary to give effect to interpretation doctrines that call for construing terms and provisions so as to give effect to the intentions of their drafters, at both the domestic ${ }^{60}$ and international ${ }^{61}$ levels. There is a rich history in intellectual property jurisprudence, and this is

\footnotetext{
${ }^{56}$ Karky (2016), p 221.

57 ('Nowadays, patents are said to be an institutional means for investors and research corporations to be rewarded, or alternatively, incentivised, for investing in research and development, for deterring the pirating of their inventions by competitors, and for harnessing a nation's inventive spirit.')

58 United States - Import Prohibition of Certain Sharp and Sharp Products (WT/DS 58/AB/R) 22 October 2001.

${ }^{59}$ Asmelash (2015), p 261.

60 See, eg, Pearce and Geddes, pp 37-8; Lonnquist (2003) 18.

${ }^{61}$ Merrils (1969), p 55.
} 
gaining recognition and coherence as increasing importance is ascribed to intellectual property rights. ${ }^{62}$

Caution is advised in seeking to identify a single, overarching philosophy of intellectual property, however, in light of the fluidity of the term 'intellectual property' noted earlier in this chapter. Today the TRIPS Agreement lumps together in a single conceptual basket all intellectual creations under the umbrella term 'intellectual property', but this was not always so. When the international legal intellectual property framework was first designed, a conceptual dichotomy split industrial and intellectual property and treated each differently. Industrial property captured the commercially driven intellectual creation, whilst intellectual property captured aesthetic creations. Hence falling within the scope of the Paris Convention for the Protection of Industrial Property ${ }^{63}$ were patents, trade marks, unfair competition, while the Berne Convention for the Protection of Literary and Artistic Works $^{64}$ focused on copyright-protectable works. The lumping together of all of these creations by the World Trade Organization in the TRIPS Agreement under the single term 'intellectual property' blurs the differences in the inspirations and incentives for their creation. Some of the historical justifications ascribed to intellectual property fit more comfortably with one category of subject matter than others. ${ }^{65}$

Vestiges of the old dichotomy of industrial and intellectual property remain nonetheless. In Australia, a seminal case considers the mould and plug used in developing racing yacht hulls and whether these are rightly the province of design law (which is industrial in nature) or copyright (which is aesthetic in nature). The High Court of Australia maintains that it is appropriate and even useful to distinguish the two environments, if only to avoid overlapping (and thus overly generous) protection:

\footnotetext{
62 Karky (2016), p 213. ('Intellectual property rights have never been more economically and politically important or controversial than they are today').

63 Paris Convention for the Protection of Industrial Property (20 Mar. 1883, last revised 14 Jul. 1967 and as amended 28 Sep. 1979), 828 U.N.T.S. 305.

${ }^{64}$ Berne Convention for the Protection of Literary and Artistic Works (9 Sep. 1886), 828

U.N.T.S. 221.

${ }^{65}$ Dutfield and Suthersanen (2008), pp 53-4 ('It is clear that Locke's theory on property is most appropriate to the protection of investment-based intellectual property such as industrial property, inventions and sound recordings. Hegelian thought, discussed further below, lends itself more to the ethical and human rights considerations, and hence is useful for explaining, for example, why we have moral rights under copyright law.')
} 
With wallpaper, a tapestry, stained glass window, piece of jewellery or Tiffany artefact, there is considerable freedom of design choice relatively unconstrained by the function or utility of the article so produced. But, as the evidence disclosed, that was not the case with the design constraints upon a class of yacht such as the JS 9000.66

These remarks inherently draw upon the presumption that the creators of the sorts of creations protected by copyright are driven to create, and unmotivated (or at least less motivated) by functionality and marketability. ${ }^{67}$ By contrast, the designer of a racing yacht hull must, of necessity, bear these objective factors in mind.

The thread running through this discussion is the significance of functional constraints, extreme for a dental mechanic, less so for a glazier or blacksmith, and depending upon the nature of the particular design brief. A horseshoe is one task; the Tijou gates, screens and grilles for St Paul's Cathedral, Hampton Court and Chatsworth by the French Huguenot ironmaster were in a very different category. ${ }^{68}$

Without ignoring these differences, all definitions of intellectual property, and indeed all categories of subject matter falling within those definitions, come together around the centrality of ideas as products of the human mind. Thus crafting a 'jurisprudence of intellectual property must be built from an understanding of the philosophical justifications for property rights to ideas. ${ }^{69}$

Identifying a universal rationale for or justification of intellectual property protection is difficult, if not impossible. 'The way patents have been justified in different countries', for example, "has always depended to some extent at least on the level of industrial development [of the country in question] - and also to whom one speaks. ${ }^{170}$ Yet one nation's intellectual property jurisprudence serves as a reference point: because of the dominant role that the United States played in bringing the TRIPS Agreement to fruition, US

\footnotetext{
${ }^{66}$ Burge v Swarbrick (2007) 232 CLR 336, para 75.

${ }^{67}$ Dutfield and Suthersanen (2008).

68 Burge $v$ Swarbrick at para 81.

${ }^{69}$ Hughes (1988) at 288.

${ }^{70}$ Dutfield and Suthersanen (2008), p 110.
} 
creative and innovative industries' priorities, needs and demands lay just below the surface of the agreement. ${ }^{71}$ Thus it seems logical to conclude that understanding the US philosophy of intellectual property is key to understanding the intentions behind the current international intellectual property framework. That philosophy draws heavily from John Locke's labor theory, which is 'subject to slightly different interpretations. One interpretation is that society rewards labor with property purely on the instrumental grounds that we must provide rewards to get labor. In contrast, a normative interpretation of this labor theory says that labor should be rewarded. ${ }^{72}$ Both versions presuppose that labour is unpleasant, but the must version specifically 'proposes that the unpleasantness of labor should be rewarded with property because people must be motivated to perform labor. ${ }^{73}$ Crucially, this theoretical underpinning emphasises recompense to individual creators, rather than duties to the broader society in terms of dissemination of ideas and inventions.

This idea that without incentive, the creative will not create is baked into the US Constitution, which ascribes to Congress the power ' $[\mathrm{t}]$ o promote the Progress of Science and useful Arts, by securing for limited Times to Authors and Inventors the exclusive Right to their respective Writings and Discoveries'.$^{74}$ Interpreting this clause, the Supreme Court famously noted:

The economic philosophy behind the clause empowering Congress to grant patents and copyrights is the conviction that encouragement of individual effort by personal gain is the best way to advance public welfare through the talents of authors and inventors ... Sacrificial days devoted to such creative activities deserve rewards commensurate with the services rendered. ${ }^{75}$

The US's leading scholar in this field has gone so far as to declare: 'In almost all of its decisions on patents, the Supreme Court has opined that property rights are needed to motivate idea-makers. ${ }^{176}$ If we assume that the TRIPS Agreement is motivated at least in

\footnotetext{
${ }^{71}$ See Field C, Negotiating for the United States. In: The making of the TRIPS Agreement: Personal insights from the Uruguay Round negotiations, pp 129, 137-154.

${ }^{72}$ Hughes (1988), p 296.

${ }^{73}$ Hughes (1988), p 303.

${ }^{74}$ (Article 1, § 8, cl 8) (emphasis added); Hughes(1988), p 303-4.

75 Mazer v Stein, 347 US 201 (1954).

${ }^{76}$ Hughes (1988), p 304.
} 
part, if not considerably, by the intentions, philosophies and needs of the country that championed its drafting, we must conclude that incentive is a key rationale for and justification of intellectual property rights. The lack of 'empirical evidence that strengthening patent law brought about a surge in innovation (as opposed to a surge in patenting)' is, in this regard, troubling. ${ }^{77}$ But if intellectual property rights do actually encourage innovation and investment in some fields or industries more than others, this is a sign that the system works, but not in the areas in which it is most needed.

In the field of medicine, data suggests that research and development expenditures are skewed to high-value pharmaceuticals. ${ }^{78}$ This is so because of the belief that it is ' $[t]$ he possibility of attaining commercial benefits...[that] encourages innovation. ${ }^{79}$ Put simply, there is greater incentive to develop anti-obesity drugs than anti-malarials. Extrapolated to climate change mitigation technologies, innovation in that field reflects the relative benefits of investing in this, compared to other fields.

The integral role of intellectual property laws in the economic growth thesis mean that 'much of creativity is dictated by market and societal needs and demands.' 80 Objective factors linked to market demand predominate in intellectual property law over the subjective 'inherent and deep need or impulse to bring a work into realisation' ${ }^{81}$ Seen in this way, intellectual property laws are necessary, and without them, the creative will simply choose to ignore the desire to create. The market is the ultimate motivator: 'While necessity may be the mother of invention, the quest for new products and technologies must fiercely compete against the demands for current consumption. ${ }^{182}$

Steering intellectual property law to fulfil its rationale and role in the context of climate change mitigation requires adopting a fundamentally different philosophy to overcome such purely utilitarian, market-based realities. The threat of catastrophic climate change,

\footnotetext{
77 Weatherall (2016), p 8.

${ }^{78}$ Bouchard et al (2010), p 174.

${ }^{79}$ Dutfield and Suthersanen (2008), p 110.

80 Dutfield and Suthersanen (2008), p 18.

${ }^{81}$ Dutfield and Suthersanen (2008), p 16.

${ }^{82}$ Rosenberg (1985) S 1.07.
} 
threatens society and its legal order, including the IPR system itself. A system premised on individual compensation for labour as an incentive for invention becomes problematic if the incentive structures involve locking up expertise which the climate change imperative demands to be rapidly disseminated. While retention of incentives remains vital in such an environment, these need to be structured to meet the demands of intergenerational justice.

Moreover, a close analysis is required to determine whether the various types of intellectual property sketched above make assumptions as to the ongoing value of private property rights into the medium- and long-term future, which come into question in a climate change threatened world. In addition, it is important to address the question of whether the current forms of intellectual property - including for example the length of patent protection - involve a bias in favour of the interests of current generations vis-à-vis future generations. Concerning the first issue, the threat of catastrophic climate change potentially makes the subject of some patents valueless in the long-term; for example, if the planet becomes too warm to feed a larger proportion of the world's population, lifestyle medications addressing problems of overeating will become redundant. Concerning the second point, overly long patent protection meshes well with incentives premised on economic development and business as usual in terms of existing energy structures. But when economic development becomes threatened by catastrophic climate change, business as usual incentive structures must be rethought. There are a range of policy mechanisms including subsidies and tax-rebates which can be adopted to shift incentive structure in this direction.

\section{$4 \quad$ Intellectual property rights in the climate change regime}

The conflict over intellectual property rights which found expression in the Paris Agreement climate change negotiations has a relatively long history as part of a broader issue of technology development and transfer. The 1992 United Nations framework Convention on Climate Change placed a general obligation on developed countries to transfer technology to developing countries, with such transfer being conditional on developing countries taking 
mitigation action. ${ }^{83}$ Similar provisions were included in the Kyoto protocol. The conditional element of these provisions was never tested given that neither instrument imposed mitigation commitments on developing countries. Nevertheless, these provisions reflected a strong justice or equity based position which developing countries have continued throughout the negotiations ever since. ${ }^{84}$ The essence of this discourse is the developing countries' argument that developed countries caused the problem of climate change through their historic greenhouse gas (GHG) emissions since the Industrial Revolution and therefore these countries have responsibility for addressing the issue. Linked to this is the argument that most of the technology essential for quickly reducing greenhouse gas emissions is possessed by the industrialised countries, and therefore it is only fair that if these countries wish to see developing countries reduce their emissions, then this technology should be transferred to developing countries.

Industrialised countries have strongly resisted this discourse, arguing that to the extent that climate -related technology is covered by intellectual property rights - particularly patents, then this is possessed largely by private companies not governments. Moreover, industrialised countries argue that intellectual property rights should not be shared or transferred as they are essential incentives for research and development. Rather than removing or limiting IPRs, the US, for example, has argued that IPRs should be strengthened in all countries as this is essential for the development of climate change-related technologies. To date, the industrialised countries have succeeded in resisting the inclusion of any explicit provisions relating to IPRs in the global climate regime (UNFCCC and Kyoto protocol and Paris agreement).

\footnotetext{
${ }^{83}$ Article 4.7 of the UNFCCC provides that: 'The extent to which developing country Parties will effectively implement their commitments under the Convention will depend on the effective implementation by developed country Parties of their commitments under the Convention related to financial resources and transfer of technology and will take fully into account that economic and social development and poverty eradication are the first and overriding priorities of the developing country Parties.'

84 This ethical principle of leadership by the industrialised countries in mitigation is reflected as a general principle in article 3 of the UNFCCC which states that "the developed countries should take the lead in reducing emissions....." See discussion of differential treatment in the chapter by Huggins and Lewis (section 3 ) in this volume.
} 
Developing countries have tended to argue that IPRs are a barrier to technology transfer. Thus, the October 2014 the Like-Minded Developing Countries (LMDC) proposal under the Durban mandated negotiations leading to the Paris Agreement called for developed country parties to "increase the provision of technology and finance and measures to address barriers to technology transfer including IP"85.

In the Paris Agreement negotiations, there was a push by a number of developing countries to include specific mention of IPRs in the agreement with proposals including the establishment of an international mechanism on intellectual property rights to facilitate access to the deployment of clean technologies for developing countries. But these proposals were strongly resisted by developed countries and the final text of the agreement dealing with technology development transfer (article 10) makes no reference to IPR's. Thus the agreement papers over the ongoing conflict between developed countries who perceive IPRs as not being a barrier for the development transfer of low carbon technologies, and developing countries who tend to perceive the IP regime "as a manifestation of the technological hegemony of the developed world, and the unwillingness to discuss IPR issues as evidence that developed countries are not genuinely interested in sharing technology." 86

\section{Conclusion}

Overcoming the ongoing North-South impasse in relation to technology transfer and IPRs will be essential to ensuring that the Paris Agreement $1.5^{\circ} / 2^{\circ} \mathrm{C}$ objective is attained which is in turn crucial for ensuring intergenerational justice. To the extent that IPRs constitute a barrier to the transfer of low carbon technologies ${ }^{87}$ intergenerational justice dictates that IPRs be modified or removed to ensure rapid mitigation of greenhouse gas (GHG) emissions. Achieving this objective requires building trust between developed and developing countries. Only with the building of such trust will we be able to move towards an

\footnotetext{
${ }^{85}$ LMDC Proposal (October 21 2014) Elements for a Draft Negotiating Text of accelerating the implementation of enhanced pre-2020 climate action www4.unfccc.int/submissions/Lists/OSPSubmissionUpload/39_99

${ }^{86}$ Klein, Carazo, Doelle, Bulmer and Higham (eds) (2017).

${ }^{87}$ see careful analysis in Rimmer (2011) and Abdel-Latif (2015), pp 103-126.
} 
understanding of shared and proportional responsibility for technology development, transfer of which IPRs form a valuable part.

Trust will need to be built by industrialised countries taking the lead in reducing GHG emissions rapidly. Trust will also be need to be built by wealthy countries contributing sufficiently to the Green Climate Fund and other international mechanisms essential for technology transfer. Building trust will also require urgent reform of the way incentives work within the IPR system to ensure that it acts as a positive incentive for the development and diffusion of low carbon technologies and not as a barrier.

This chapter has argued that intergenerational justice, interpreted in a manner sensitive to the equally important needs of intragenerational justice provides a valuable framework for a reform agenda in this area.

A failure to build trust and take strong mitigation action will potentially have catastrophic impacts for future generations. In terms of IPRs this would entail that material which is potentially subject to IPRs may decline in value or be lost altogether. ${ }^{88}$ This is true in relation to for example, biological material, and would apply with particular force in relation to catastrophic climate change. Even beyond this, catastrophic climate change would bring into question what relevance at all the IPRs system would have. Thus, various elements of the existing IPR system include assumptions which will not be sustainable in a world threatened by catastrophic climate change.

The foundational justification of the whole IPR system has involved an assumption of evergrowing wealth and progress - achieved through the provision of (limited) private monopoly rights designed to create an incentive for innovation benefiting an ever expanding the common pool of ideas. The threat of climate change, challenges to its core these foundational assumptions.

\footnotetext{
88 Thanks to Ben Boer for pointing this out.
} 


\section{References}

\section{Journal Articles}

Abdel-Latif A (2015) Intellectual Property Rights and the transfer of climate change technologies: issues, challenges, and way forward, Climate Policy, 15: 1, pp 103-126.

Asmelash HB (2015) Energy Subsidies in WTO Dispute Settlement: Why Only Renewable Energy Subsidies are Challenged, 18 Journal of International Economic Law, p 261.

Beckerman-Rodau A (2011) The Problem with Intellectual Property Rights: Subject Matter Expansion, Yale Journal of Law and Technology, 13: 1, http://digitalcommons.law.yale.edu/cgi/viewcontent.cgi?article=1064\&context=yjolt.

Beckerman-Rodau A (1994) Are Ideas Within the Traditional Definition of Property?:

A Jurisprudential Analysis 47 Arkansas Law Review, p 603.

Bouchard RA et al (2010), Empirical Analysis of Drug Approval-Drug Patenting Linkage for High Value Pharmaceuticals, Northwestern Journal of Technology and Intellectual Property, 8:2, pp 174-227.

https://scholarlycommons.law.northwestern.edu/cgi/viewcontent.cgi?referer=https://w ww.google.com.au/\&httpsredir=1\&article $=1102 \&$ context=njtip.

Caney S (2009a) Climate Change and the Future: Discounting for Time, Wealth and Risk 40(2) Journal of Social Philosophy, p 163.

Collier R (2013) Drug Patents: innovation v accessibility 9 Canadian Medical Association Journal $\mathrm{p} 185$.

de Vuyst B et al (2003) Exceptions to Intellectual Property Rights: Lessons from WTO-TRIPS Panels' 10(4), Murdoch University Electronic Journal of Law.

Donnelly J (2007) The Relative Universality of Human Rights 29 Human Rights Quarterly, p 281.

Forsyth T (2005) Enhancing Climate Technology Transfer through greater public-private cooperation: Lessons from Thailand and the Philippines, National Resources Forum 29, pp 165-176.

Hughes J (1988) The Philosophy of Intellectual Property, 77 Georgetown Law Review p 287 and 291.

Lonnquist T (2003) The Trend Towards Purposive Statutory Interpretation: Human Rights at Stake, Revenue Law Journal 13:1, Article 3.

Merrils JG (1969) Two Approaches to Treaty Interpretation, 4 Australian International Law Journal, p 55.

Sceats S and Breslin S (2012) China and the International Human Rights System, Chatham house

http://www.chathamhouse.org/sites/default/files/public/Research/International\%20Law Lr1012 sceatsbreslin.pdf $>$ accessed 23 August 2013, p 8.

\section{Books and Chapters}

Albin, C (2001) Justice and Fairness in International Negotiation. Cambridge University Press, Cambridge.

Bowersox, J (2002) Sustainability and environmental justice: a necessary connection. In Gillroy, JM and Bowersox, J (eds) The Moral Austerity of Environmental Decision-Making, Sustainability, Democracy, and Normative Argument in Policy and Law, Duke University Press, p 247. 
Bessen J and Meurer M (2008) Patent Failure: How Judges, Bureaucrats and Lawyers Put Innovators at Risk, Princeton University Press.

Caney S (2009b) Climate Change, Human Rights and Moral Thresholds. In S Humphreys (ed), Human Rights and Climate Change, Cambridge University Press; reprinted in S Gardiner, et al (eds) (2010) Climate Ethics Essential Readings, Oxford University Press, p 167.

Ciplet D, Timmons Roberts J and Khan MR (2015) Power in a Warming World: The New Global Politics of Climate Change and the Remaking of Environmental Inequality, MIT Press.

Dutfield G and Suthersanen U (2008) Global Intellectual Property Law, Edward Elgar.

Drahos P (2011) Six Minutes to Midnight: Can Intellectual Property Save the World? In: Bowrey $\mathrm{K}$ et al (eds), Emerging Challenges in Intellectual Property, Oxford University Press, $\mathrm{p} 31$.

Forrest HA (2017) Protection of Geographic Names in International Law and Domain Name System, Wolters Kluwer, $2^{\text {nd }}$ ed.

Gervais D (2012) The TRIPS Agreement: Drafting History and Analysis 15 (4th ed.), Sweet \& Maxwell.

Greenhalgh C and Rogers M (2010) Innovation, Intellectual Property, and Economic Growth, Princeton University Press.

Hayward T (2005) Constitutional Environmental Rights, Oxford University Press.

Karky R (2016) Intellectual Property Rights and Foreign Direct Investment. In: Perry M (ed) (2016) Global Governance of Intellectual Property in the $21^{\text {st }}$ Century: Reflecting Policy Through Change, Springer, p 213.

Klein D, Carazo MP, Doelle M, Bulmer J and Higham A (eds) (2017) The Paris Agreement on Climate Change, Analysis and Commentary, Oxford University Press, Oxford.

Kole C (ed) Genomics and Breeding for Climate-Resilient Crops, Springer.

Lawrence P (2014) Justice for Future Generations Climate Change and International Law. Edward Elgar, Cheltenham, pp 48-50.

Rimmer M (2011) Intellectual Property and Climate Change: Inventing Clean Technologies, Edward Elgar, Cheltenham.

Richardson RS and Gaisford JD (2017) North-South disputes over the protection of intellectual property. In: George A (ed) (2017) Globalisation and Intellectual Property, Routledge.

Perry M (2016) The Changing Face of Intellectual Property. In: Perry M (ed), Global Governance of Intellectual Property in the $21^{\text {st }}$ Century: Reflecting Policy Through Change, Springer.

Rosenberg PD (1985) Patent Law Fundamentals ( $2^{\text {nd }}$ ed) S 1.07.

Shue H (2014) Climate Justice Vulnerability and Protection. Oxford University Press, Oxford.

Shue H (Nov 2015) Last Opportunities: Future Human Rights Generate Urgent Present Duties. In: Global Policy Journal, special issue, Marcello di Paola and Daanika Kamal (eds.), Climate Change and Human Rights: The 2015 Paris Conference and the Task of Protecting People on a Warming Planet.

Shue H (1980) Basic Rights: Subsistence, Affluence and US Foreign Policy. Princeton University Press, p 24 \& p 125See, eg, Jaffee A and Lerner J (2006) Innovation and its Discontents: How Our Broken Patent System is Endangering Innovation and Progress, and What to Do About It, Princeton University Press.

Vanderheiden S (2008) Atmospheric Justice, Oxford University Press, Oxford 
Weatherall K (2016) IP in a changing International Environment. In: Perry M (ed), Global Governance of Intellectual Property in the $21^{\text {st }}$ Century: Reflecting Policy Through Change, Springer, $\mathrm{p} 8$. 